\title{
Bio Efficacy Assay of Laccase isolated and Characterized from Trichoderma viride in Biodegradation of Low Density Polyethylene (LDPE) and Textile Industrial Effluent Dyes
}

\author{
D. Alwin Johnnie ${ }^{1,2 *}\left(\mathbb{D}\right.$, Reya Issac ${ }^{2}$ (D) and M. Lakshmi Prabha² \\ ${ }^{1}$ Department of Biotechnology, Sri Shakthi Institute of Engineering and Technology, \\ Coimbatore - 641 001, Tamil Nadu, India. \\ ${ }^{2}$ Department of Biotechnology, Karunya Institute of Technology and Sciences, Coimbatore - 641114 , \\ Tamil Nadu, India.
}

\begin{abstract}
This study is based on the biosynthesis of laccase enzyme from fungi Trichoderma viride and its exploitation in biodegradation of polyethylene using Laccase mediator system (LMS -Laccase + 1-HBT) in Low Density Polyethylene (LDPE) and in biodegradation of textile industrial effluent dyes. In different parts of our lifespan we have seen the numerous types of plastics are getting degraded by various methods, still the average time to completely degrade a plastic bottle is at least $\mathbf{4 5 0}$ years.Similarly industry produces over $\mathbf{3 . 6}$ thousand individual textile dyes today and utilizes more than $\mathbf{8 0 0 0}$ toxic chemicals in numerous methods for textile manufacture comprising dyeing and printing. As polyethylene and textile industrial effluent dyes a r e causing severe hazardous effect on environment and health issues in all kind of living organisms, it is necessary to degrade plastics and textile industrial effluent dyes in rapid way. Recently researchers have come up with an idea of degrading plastic and textile industrial effluent dyes with the help of microorganisms and enzymes much faster than normal rate. The Laccase enzyme extracted was tested for its optimum temperature and pH. Lowry's method is used for protein estimation. A control and sample LDPE was subjected to LMS. The tensile strength and elongation of the sample was less than that of the control after 5 days of treatment. This study showed that laccase together with 1-HBT helps to biodegrade polyethylene. The purified laccase enzyme was used for the pretreatment assay and post treatment assay. The Laccase degrades certain reactive dyes like Congo red, Acid Red, Methylene Blue, Brilliant Blue, Metallic Blue and Black. Thus recommends the application of laccase in textile dye colour removal (bioremediation).
\end{abstract}

Keywords: Polyethylene, laccase, Laccase mediator system (LMS), Low Density Polyethylene (LDPE), hydroxybenzotriazole (HBT), biodegradation, tensile strength, decolourization

C The Author(s) 2021. Open Access. This article is distributed under the terms of the Creative Commons Attribution 4.0 International License which permits unrestricted use, sharing, distribution, and reproduction in any medium, provided you give appropriate credit to the original author(s) and the source, provide a link to the Creative Commons license, and indicate if changes were made. 


\section{INTRODUCTION}

Laccase (benzenediol: oxygen oxidoreductase; EC 1.10.3.2) is a blue-copper oxidoreductase enzyme which catalyze the oxidation of various substrates together with phenolic compounds along with the reduction of molecular oxygen to water (Karla Mayolo-Deloisa, 2020).

Laccase is an enzyme with possible oxidation capabilities. It belongs to those enzymes which have the inherent properties of the production of reactive radicals, and because of its inaccessibility in the commercial field; its use in many fields has been overlooked. There are numerous sources of species developing laccases, such as bacteria, fungi and plants (Muhammad, 2012). Laccase is one of the main enzymes that destroy lignin to solve recent environmental problems. A research was conducted on fungi to identify the production potential of laccases for industrial and environmental applications (Thakkar, 2020).

Laccase is a sporadic enzymes that have been experimented since the $19^{\text {th }}$ century. Laccase was first termed in 1883 by Yoshida when he isolated it from Japanese lacquer tree, Rhus vernicifera (C.F.Thurston, 1994) exudates. The oxidation reaction associated with a reduction of molecular oxygen by four electrons to water is catalyzed by one of the adaptable enzyme Laccase. They are multi-copper enzymes which can be extracted from higher plants, bacteria, insects and fungi. They have the gift of degrading lignin and are present in many white-red champignons. Laccases find wide commercial application within food industry, textile industry, pulp and paper industry, synthetic chemistry, cosmetics, bioremediation of soil and biodegradation of phenolic pollutants in environmental (Cuoto \& Herrera, 2006).

In 1791, in Germany, the genus Trichoderma was described and four species were originally described. Four species were recognized in 1927 by Gilman and Abbott. These species have been distinguished based on the color and form of their conidia and the morphology of the colony. The majority of species have been classified as T. Lignorum ( $=\mathrm{T}$. viride) because of or as T. because of of its globose conidia or as T. koningii because of its oblong conidia (Gorantla Venugopala Raju, 2013) .All eukaryotic organisms especially fungus which includes microorganisms like yeasts and molds, also the more acquainted mushrooms. Soil-born champignons like Trichoderma in the Hypocreaceae family, where they are the most prevalent. Many species within this genus can be defined as opportunistic virulent symbionts of plants. This refers to the capacity of several species of Trichoderma to form mutualist endophytic relationships with different species of plants. Trichoderma harzianum, Trichoderma viride, longibrachiatum and reesei are four different species. Every species has defining features and potentials but mainly they are differentiated by what they ingest. By choosing strains that yield a definite enzyme, and culturing these in suspension, can synthesize different industrial quantities of enzyme. Trichoderma viride is a fungus and a biofungicide. A belief was there like it is the only species of Trichoderma for a prolong period and recognized as the "green mold disease of mushrooms". It degrades both chitin and cellulose which are used as their food source. An adept, Scotty Real, stated that "Its capability to degrade both compounds make it very adaptable". This species has ability to grow on wood (cellulose) and fungi (chitin). Trichoderma viride have voracious appetites for all mould. It may also be used for seed and soil treatment for plant diseases like red rot and blot diseases in sugarcane plant caused by various fungal plant pathogens (Gochev \& Krastanov, 2007).

The use of polythene is growing day by day, and now it can be seen that in almost every life operation, polythene is used. India's polythene demand is projected to increase by 129 per cent by 2023 , it has been estimated. The increased use of polythene would also increase the amount of contamination caused by it, affecting almost any kind of climate, including terrestrial and aquatic biomes (Alka Grover, 2015). In earlier days phenol and formaldehyde were used to manufacture the first plastic (polyethylene) based on a synthetic polymer, with the first feasible and inexpensive production method designed in 1907, by Leo Hendrik Baekeland, Belgian-born American living in New York state.

High-density polyethylene and low density polyethylene are the long chain polymers of ethylene, which has been widely used in packaging industry due to its effectiveness and 
versatile nature such as light weight, inexpensive, durable, energy efficient and can be easily processed. (Nupur Ojha et al., 2020)

One of the most robust plastic polymers is known to be polyethylene. Non-biodegradable polyethylene practically accumulates in the atmosphere, posing an ecological risk to humans and wildlife (Miriam Santo, 2013). It is the material use to produce shopping bags, shampoo bottles, kids toys and even bullet resistant jackets. It has a very simple structure for such a multipurpose material, the simplest of any commercial polymers. Polyethylene has many reported side effects in humans. One such is that it can cause mild irritation of the skin. When inhaled it caused some people to experience proximal scleroderma, Reynaud syndrome, joint involvement, pulmonary manifestation. It can also induce an asthma. They also found the chemical to be toxic to the immune system. Additionally, it has been found to be a possible carcinogen. Polyethylene affected body systems include the integumentary system, respiratory system, immune system, skeletal system, and muscular system. Both chemical and biological methods are incorporated with different attempts to control the problem. Chemical methods have only contributed to air pollution being encouraged by discharging harmful gasses into the atmosphere; whereas biological methods have been found to be environmentally friendly but expensive. This paves the way for the degradation of polyethylene sheets (HDPE, LDPE), using fungal isolates.

Similarly a big pollution problem has been caused by the textile being and finishing industry because it is one among the most chemically exhaustive industries on this planet, and the best polluter of pure water (after agriculture). Industry produces over 3.6 thousand individual textile dyes today. The industry utilizes more than 8000 chemicals in numerous methods of textile manufacture comprising dyeing and printing. Most of chemicals are toxic to humans and deteriorates directly or indirectly the human health. Water consumption of an regular sized textile mill manufacturing $8000 \mathrm{~kg}$ of cloth per day is about $1,60,000$ litres every day. Dyeing utilizes $16 \%$ of water and $8 \%$ by printing.

Textile effluent is the major reason for environmental ruin and human health hazards.
Chemicals available in these textile effluent vaporizes in to the air, and when we inhale or is absorbed through our skin, it enables allergic reactions and may cause health issues to younger generation even before birth. The waste water that streams in the drains rusts the sewage pipes. If it is allowed to flow into drains and rivers, it affects the quality of drinking water which makes it unfit for humans to drink and use it for household purposes (Rita Kant, 2011). Biological oxygen demand (BOD) and the Chemical oxygen demand (COD) were two vital tests utilized to characterize the textile industrial effluent wastewater (Ouissal Assila, 2020).

About $90 \%$ of reactive textile dyes entering activated sludge sewage treatment plants are believed to pass through unchanged and are discharged to rivers. With physical and chemical processes, and occasionally deterioration, not all commonly used dyes can be degraded and/ or eliminated. Around $\mathbf{1 0 0}$ liters of water is used by the conventional textile finishing industry to process around $1 \mathrm{~kg}$ of textile materials. New closed-loop technologies, like the reuse of dye effluents that are microbially or enzymatically processed, could help minimize this enormous consumption of water (Elias Abadulla et al, 2020).

More than $80 \%$ of Indigo Carmine, Remazol Brilliant Blue R, Reactive Orange 16 and Acid Red 27 dyes could be decolorized by the enzyme laccase within 1 hour (Aleksandra Goralczyk-Binkowska, 2020). In addition to removing heavy metal $(\mathrm{Cd}, \mathrm{Cr}, \mathrm{Ni}$ and $\mathrm{Pb})$, viability between species and functional group activation in the presence of heavy metal after comparison with some fungal isolates from the terrestrial world, this study aimed to find suitable laccase producing fungi to help greener the environment by decolourizing industrial dyes (Amutha, 2015). The role of laccase in the degradation of lignin and phenolic compounds has been studied in various biotechnological applications, such as the degradation of textile dyes, the bioremediation of some toxic chemical waste, wastewater and soil treatment, and also the development of biosensors (A.I. El-Batal et al., 2015).

\section{MATERIALS AND METHODS FUNGAL CULTURES USED IN THE STUDY}

The fungal Trichoderma viride was 
brought commercially in a powdered form from the Mass Cultivation of Trichoderma spp. Laboratory, Department of Agriculture Sciences, Karunya Institute of Technology and Sciences, Coimbatore. PREPARATION OF MEDIUM FOR THE FUNGAL CULTURE

Using OMA, PDA, the fungal culture has been sub-cultured. These are the common microbiological growth media, commonly used to grow fungi and bacteria.

\section{Preparation Of OMA}

The OMA was brought commercially from Hi-Media with the following composition. The OMA was taken in a $250 \mathrm{ml}$ Erlenmeyer flask for about $3.8 \mathrm{gm}$, and added $100 \mathrm{ml}$ of distilled water. The medium was sterilized for 15-20 minutes or 15 psi in an autoclave at $121^{\circ} \mathrm{C}$ and cooled to room temperature for organism inoculation.

\section{Culturing Of Fungal Species}

The fungal cultures were inoculated in the laminar chamber. The sterilized agar medium was poured into the Petri plate and solidified. The powdered form of Trichoderma viride was taken for about $1 \mathrm{~g}$ and diluted with $3 \mathrm{ml}$ distilled water. It was then added into PDB and PDA. The cultures were kept for incubation at 27-30 degree celsius for 7-10 days. After incubation the spores were taken for the production of the laccase enzyme.

Table 1. Composition for Citrate Phosphate Buffer

\begin{tabular}{|c|c|c|}
\hline No. & Ingredients & Amount Required \\
\hline 1 & $\begin{array}{l}\text { Dibasic sodium } \\
\text { phosphate }\end{array}$ & $0.9149 \mathrm{~g}$ \\
\hline 2 & Citric acid & $0.4668 \mathrm{~g}$ \\
\hline 3 & Distilled water & $100 \mathrm{ml}$ \\
\hline
\end{tabular}

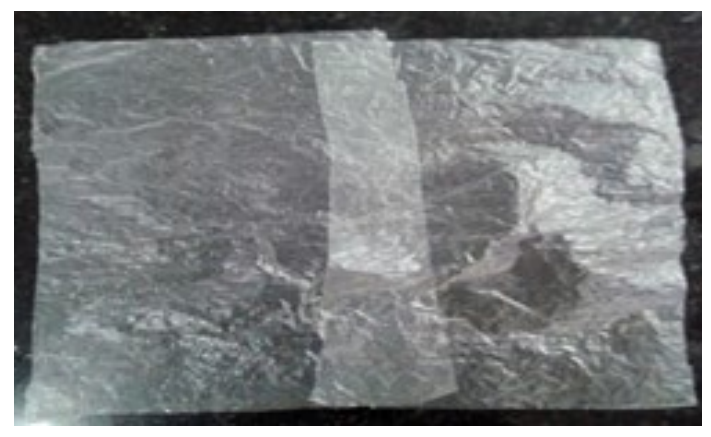

Fig. 1. Low Density Polyethylene

\section{Preparation of Basal Medium}

Water containing a mineral supplement with the following composition (Kalra et al., 2013) is autoclaved for $20 \mathrm{~min}$ at $121^{\circ} \mathrm{C}$. Once chilling is over, cultures were inoculated with sterile techniques using forceps from the growing fungal colony in to OMA. After inoculation the medium was kept in rotary shaker for 36 hours, the free liquid was separated by refrigerated centrifugation at $10,000 \mathrm{rpm}$ for $20 \mathrm{~min}$ at $4^{\circ} \mathrm{C}$ to separate supernatant and pellet. The supernatant constituted the crude enzyme extract.

\section{Preparation of Citrate Phosphate Buffer}

The pellet was inoculated in citrate phosphate buffer to purify the crude enzyme. The buffer containing the composition showed in table 1, along with the pellet was stirred using magnetic stirrer for 20 mins and left over night in refrigerator, this method was repeated twice as the buffer was changed, throughout the process the $\mathrm{pH}$ was maintained at 5 .

\section{Guaiacol Assay}

Kalra et al., in 2013 stated that the sterilized agar medium was poured into the Petri dish and allowed to solidify Guaiacol Oxidation for laccase enzyme. Using UV Spectrometer, the reddish brown color produced as a result of guaiacol oxidation by laccase is used to test enzyme activity at $450 \mathrm{~nm}$. The guaiacol assay composition is mentioned in table 2 below.

\section{Enzyme Activity}

Enzyme activity is a measure of catalytic ability and there are two methods of measuring the enzyme activity: one is to calculate the decrease in the substrate concentration over a period of time, and the other is to measure the

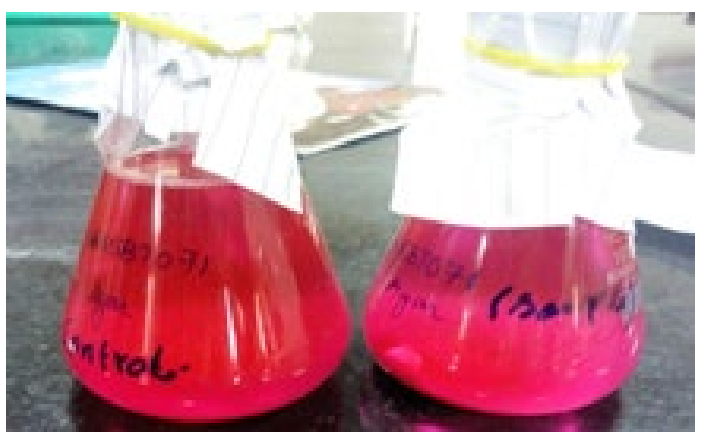

Fig. 2. Low Density Polyethylene Sheets in Rose Bengal Agar 
increase in the product concentration after a period of time.Enzyme activity can be calculated using the formula given below:

Enzyme activity $=A * V / t * e * v$

A-Absorbance

$\mathrm{V}$ - Total mixture of the volume

$\mathrm{t}$ - Incubation time

v- Enzyme volume

e- Extinction co-efficient

Relative activity percentage $=($ Absorbance $/$ control $) * 100$.

\section{Relative}

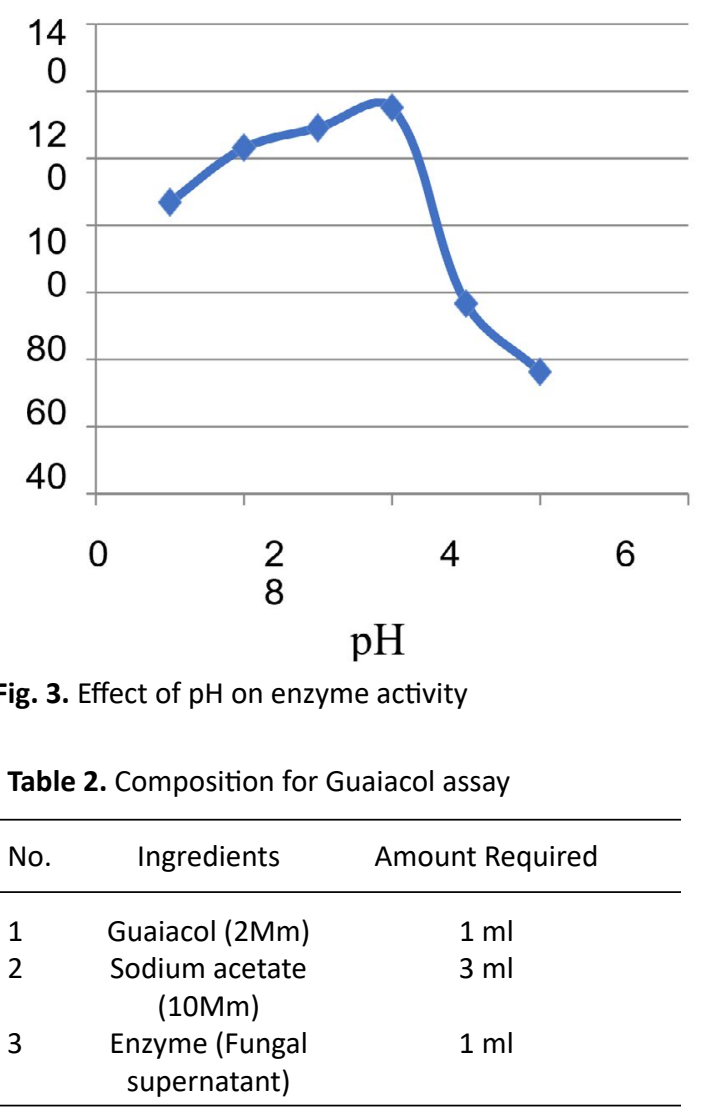

Table 3. Measurements for polyethylene

\begin{tabular}{ccc}
\hline No. & Parameter & $\mathrm{cm}$ \\
\hline 1 & Length & 12.2 \\
2 & Breadth & 7
\end{tabular}

\section{Preparation of Polyethylene}

The low density polyethylene sheet is prepared for biodegradation assay.

\section{Density Of Polyethylene}

Fill $500 \mathrm{ml}$ measuring cylinder with water, lower the sheet of polyethylene into the water until it is fully sub-merged (avoid formation of bubbles as it may cause variations in accuracy). Measure the increase level of water; this is the volume of plastic in $\mathrm{cm}^{3}$. For example: If the

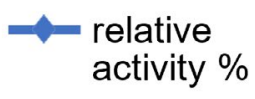

Table 4. Composition for Biodegradation assay

\begin{tabular}{lcc}
\hline No. & Ingredients & Amount Required \\
\hline 1 & Rose Bengal & $3.28 \mathrm{gm}$ \\
& Agar & \\
2 & Enzyme & $2 \mathrm{ml}$ \\
3 & Distilled water & $100 \mathrm{ml}$ \\
\hline
\end{tabular}

Table 5. Wavelengths for Different Dyes

No. Textile Dye Color Wavelength $(\mathrm{nm})$

\begin{tabular}{lcc}
\hline 1 & Congo Red & 650 \\
2 & Acid Red & 650 \\
3 & Methylene Blue & 465 \\
4 & Black & 700 \\
5 & Brilliant Blue & 465 \\
6 & Metallic Blue & 465 \\
\hline
\end{tabular}


increase in water level is $625 \mathrm{ml}$, then $625-500=$ 125. $1 \mathrm{ml}$ of water $=1 \mathrm{~cm} 3$, i.e. Volume of plastic $=$ $125 \mathrm{~cm} 3$. The density of plastic can be calculated using the formula given below:

Density $=$ mass $/$ volume; Unit $=\mathrm{gm} / \mathrm{cm}^{3}$.

\section{Decolorization of The Dyes}

The crude enzyme was used for the decolorization of the textile dyes. The enzyme was added into the dyes in the ratio of 2:5. The color changes was observed visually and also by the change in the absorbance (OD) of the dyes. The percentage of decolorization was found by using the formula ((initial absorbance-final absorbance) / initial absorbance) $\times 100$.

\section{Wavelength of The Dyes}

The wavelengths ( $\mathrm{nm}$ ) taken to measure the OD or the absorbance of the different dyes are shown in the table 5 .

\section{EXPERIMENTAL RESULTS}

In this present study, the enzyme laccase was isolated from the fungal species Trichoderma viride. The enzyme isolated was further used for the biodegradation of polyethylene (LDPE).

\section{Enzyme Activity}

From the calculations done by using the above formula the enzyme activity of laccase was found to be $7.31 \mathrm{U} / \mathrm{ml}$.

\section{Relative activity \%}

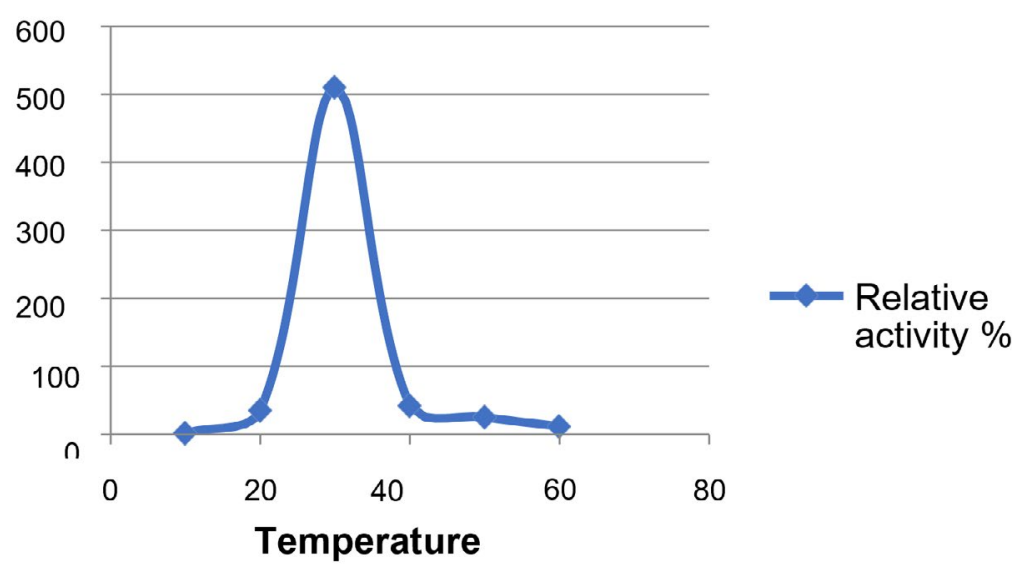

Fig. 4. Effect of temperature on enzyme activity

\section{CONGO}

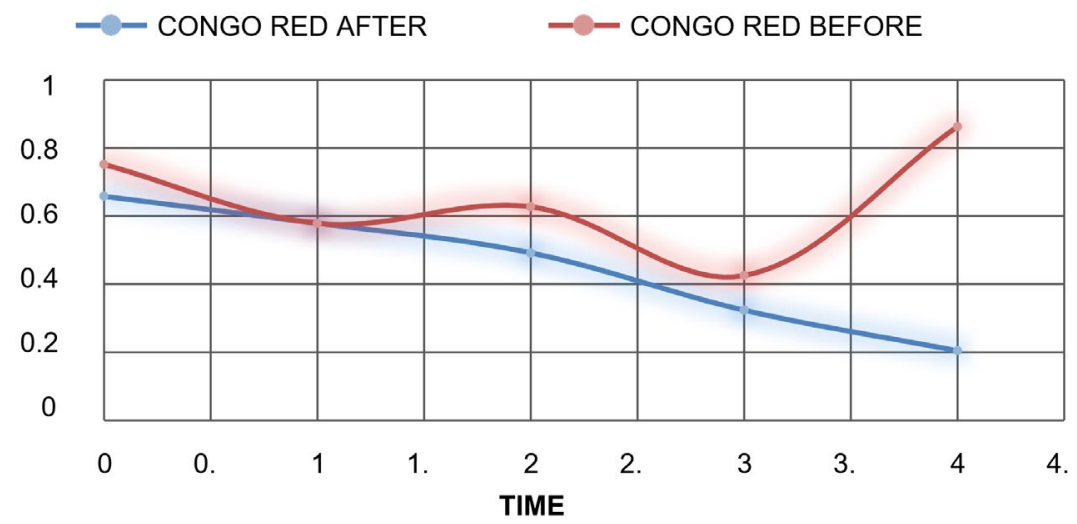

Fig. 5. Congo red 


\section{Effect of pH on Enzyme Activity}

Effect of $\mathrm{pH}$ on enzyme activity is analyzed and the optimum $\mathrm{pH}$ was found to be 4 and 5 .

Effect of Temperature on Enzyme Activity

The temperature effect on enzyme activity is analyzed and the optimal temperature was $30^{\circ} \mathrm{C}$ to $40^{\circ} \mathrm{C}$ respectively.

\section{Biodegradation of Polyethylene}

The sheets of polyethylene were kept in incubation for 10 days. After 10 days the mass and density of the sheets were analyzed to check the biodegradation level.

\section{Before Treatment}

\section{Mass $=13 \mathrm{~g}$, Volume $=0.02 \mathrm{ml}$} i.e. $0.02 \mathrm{ml}=0.02 \mathrm{~cm}^{3}$

Density $=$ mass $/$ volume $=13 / 0.02=6.5 \mathrm{~g} /$

\section{After Treatment}

$\mathrm{cm}^{3}$.

$$
\begin{aligned}
& \text { Mass }=12.7 \mathrm{~g}, \text { Volume }=0.02 \mathrm{ml} \\
& \text { Density }=\text { mass } / \text { volume }=11 / 0.02=6.35 \mathrm{~g} /
\end{aligned}
$$

\section{Biodegradation of Tetile Dyes}

The enzyme isolated was further used for the decolorization of the textile dyes.

Absorbance of The Textile Dyes Before Treating With The Laccase Enzyme

The absorbance of the textile dyes were taken by checking the OD of the textile dyes in the interval of one hour respectively.

\section{Absorbance of The Textile Dyes After Treating} With The Laccase Enzyme

The laccase enzyme was added to the dyes in the ratio of 2:5. The absorbance of the textile dyes $\mathrm{cm}^{3}$.

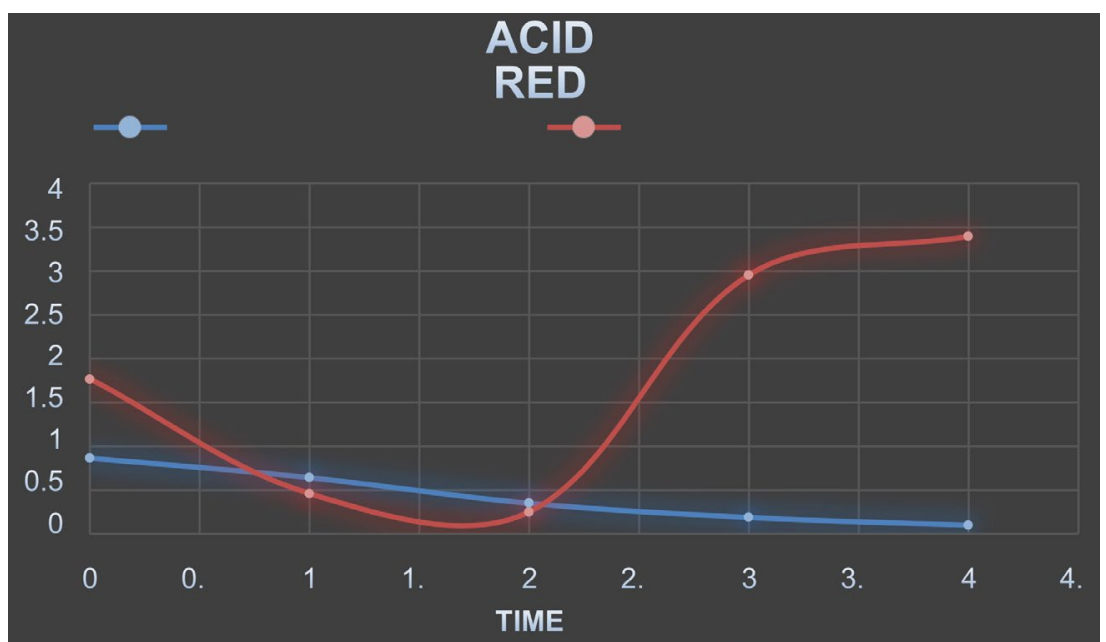

Fig. 6. Acid Red

Table 6. Absorbance of enzyme at different $\mathrm{pH}$

\begin{tabular}{lcccccc}
\hline $\mathrm{pH}$ & 1 & 2 & 3 & 4 & 5 & 6 \\
\hline Absorbance at 450 nm & 0.696 & 1.236 & 0.363 & 0.213 & 0.612 & 0.137 \\
Control & 0.801 & 1.199 & 0.332 & 0.185 & 0.925 & 0.377 \\
Relative activity \% & 86.89 & 103.085 & 109.337 & 115.135 & 56.61 & 36.339 \\
\hline
\end{tabular}

\begin{tabular}{|c|c|c|c|c|c|c|}
\hline Celsius & $10^{\circ}$ & $20^{\circ}$ & $30^{\circ}$ & $40^{\circ}$ & $50^{\circ}$ & $60^{\circ}$ \\
\hline Absorbance at $450 \mathrm{~nm}$ & 0.003 & 0.147 & 1.055 & 0.796 & 0.276 & 0126 \\
\hline Control & 0.210 & 0.423 & 0.207 & 1.912 & 1.115 & 1.138 \\
\hline Relative Activity \% & 1.428 & 34.751 & 509.66 & 41.631 & 24.753 & 11.072 \\
\hline
\end{tabular}

Table 7. Absorbance of the enzyme at different temperature 
were taken by checking the $O D$ of the textile dyes in the interval of one hour respectively.

\section{DISCUSSION}

In this present study, biodegradation of polyethylene was done by the biological method of using enzyme. The enzyme used was laccase isolated from the fungal species Trichoderma viride. Laccase is a primary enzyme which is used for the biodegradation of polyethylene. Here culture filtrate was obtained that contains a large amount of laccase. Different factors, such as type and quantity of nutrients, $\mathrm{pH}$ factor and inducers, can affect the output of lacquers by influencing the expression of laccase (Giardina et al, 2010; Parenti et al, 2013). Here the laccase producing ability using Trichoderma viride was investigated. The polyethylene sheets were subjected to two

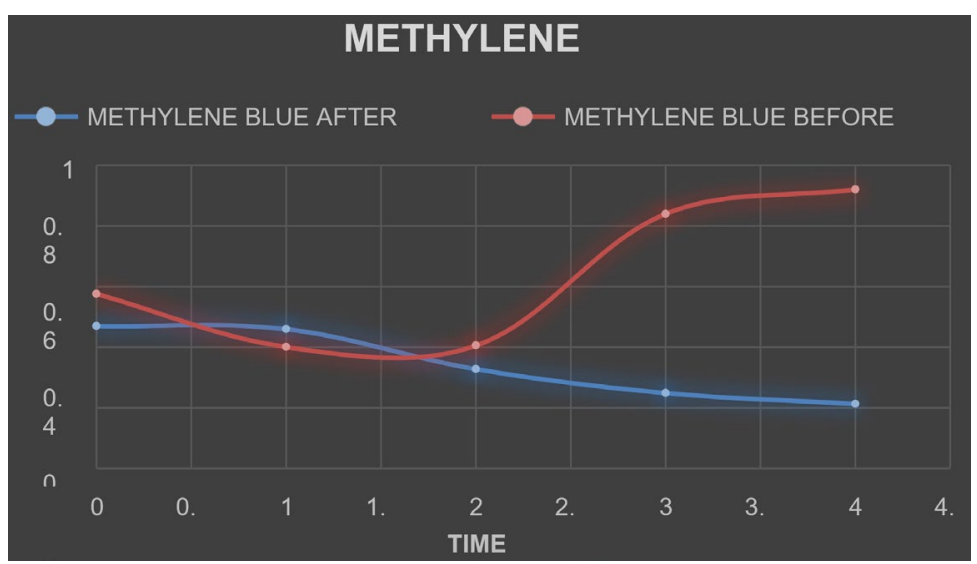

Fig. 7. Methylene Blue

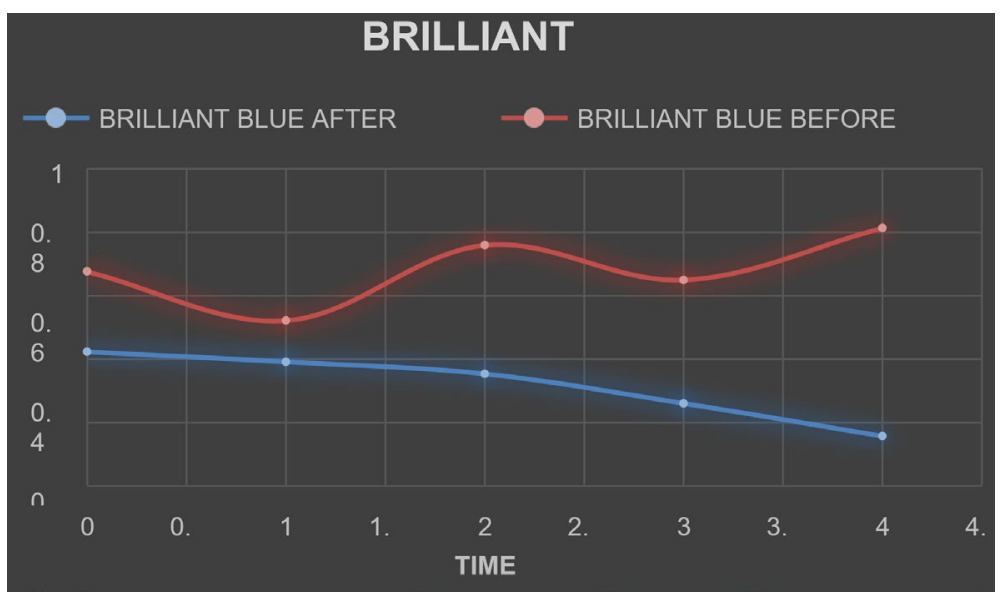

Fig. 8. Brilliant Blue

Table 8. Absorbance of the dyes before Treatment

\begin{tabular}{|c|c|c|c|c|c|c|}
\hline Time & $\begin{array}{c}\text { Congo } \\
\text { Red }\end{array}$ & $\begin{array}{l}\text { Acid } \\
\text { Red }\end{array}$ & $\begin{array}{l}\text { Methylene } \\
\text { Blue }\end{array}$ & $\begin{array}{c}\text { Metallic } \\
\text { Blue }\end{array}$ & $\begin{array}{c}\text { Brilliant } \\
\text { Blue }\end{array}$ & Black \\
\hline 0 & 0.752 & 1.767 & 0.575 & 0.676 & 0.335 & 1.237 \\
\hline 1 & 0.579 & 0.459 & 0.4 & 0.521 & 0.4 & 2.155 \\
\hline 2 & 0.628 & 0.249 & 0.405 & 0.759 & 0.405 & 1.333 \\
\hline 3 & 0.426 & 2.956 & 0.839 & 0.649 & 0.689 & 2.424 \\
\hline 4 & 0.863 & 3.398 & 0.920 & 0.813 & 0.839 & 2.679 \\
\hline
\end{tabular}


different conditions, one was kept as control and the other was treated with $2 \mathrm{ml}$ of laccase enzyme in Rose Bengal Agar. The mass and density of the plastic sheet were calculated initially and finally using the formula:
Density $=$ mass $/$ volume $\left(\mathrm{g} / \mathrm{cm}^{3}\right)$.

After 0 days of incubation the density of the polyethylene sheet that was subjected to the laccase was reduced by $0.15 \mathrm{~g} / \mathrm{cm}^{3}$. To increase the

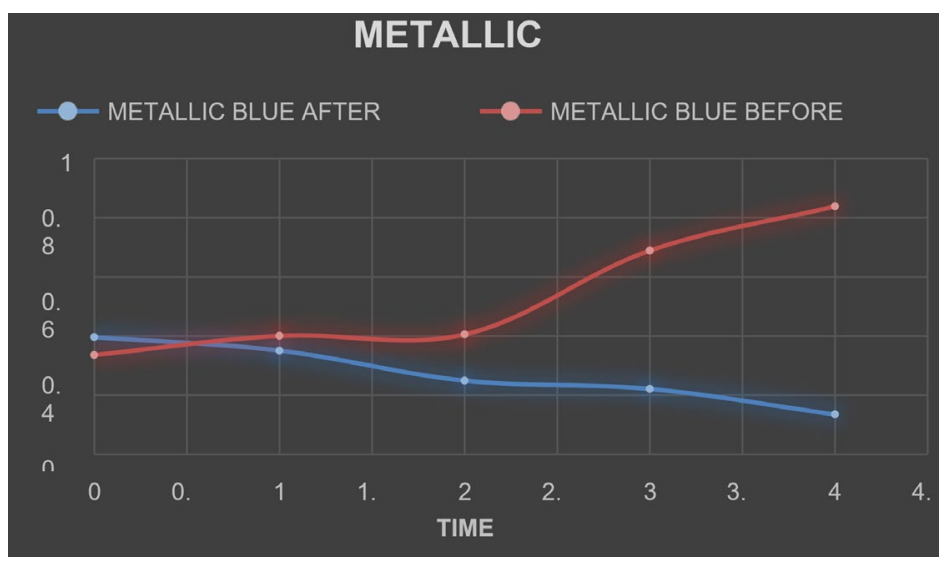

Fig. 9. Metallic Blue

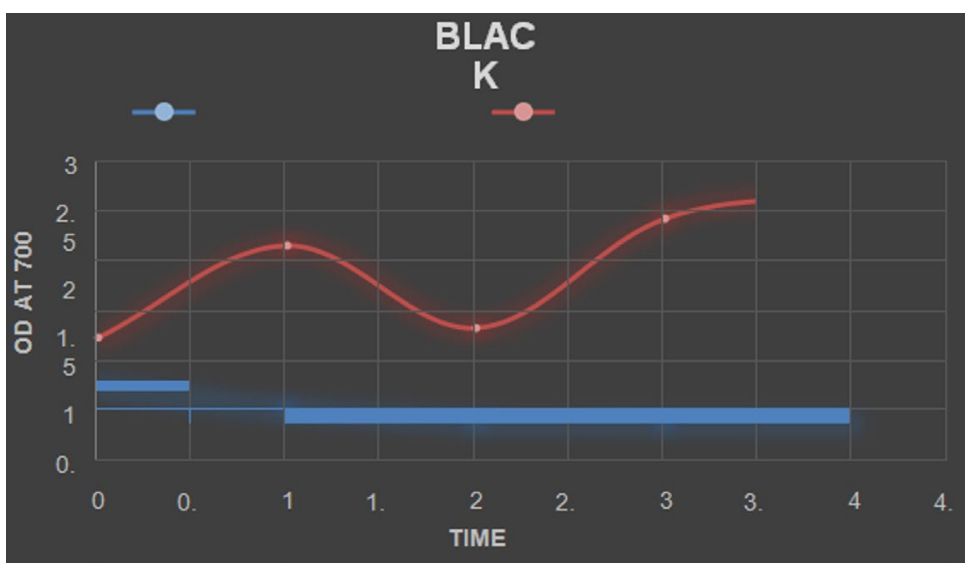

Fig. 10. Black

Table 9. Absorbance of the dyes after Treatment

\begin{tabular}{|c|c|c|c|c|c|c|}
\hline Time & $\begin{array}{l}\text { Congo } \\
\text { Red }\end{array}$ & $\begin{array}{l}\text { Acid } \\
\text { Red }\end{array}$ & $\begin{array}{l}\text { Methylene } \\
\text { Blue }\end{array}$ & $\begin{array}{l}\text { Metallic } \\
\text { Blue }\end{array}$ & $\begin{array}{c}\text { Brilliant } \\
\text { Blue }\end{array}$ & Black \\
\hline 0 & 0.659 & 0.864 & 0.47 & 0.424 & 0.396 & 0.75 \\
\hline 1 & 0.579 & 0.642 & 0.46 & 0.392 & 0.35 & 0.527 \\
\hline 2 & 0.492 & 0.349 & 0.328 & 0.354 & 0.249 & 0.397 \\
\hline 3 & 0.324 & 0.186 & 0.249 & 0.261 & 0.221 & 0.384 \\
\hline 4 & 0.205 & 0.095 & 0.213 & 0.158 & 0.135 & 0.37 \\
\hline
\end{tabular}

Table 10. Percentage of Dye Degradation

\begin{tabular}{lccccccc}
\hline $\begin{array}{l}\text { Textile Dyes } \\
\text { Colors }\end{array}$ & $\begin{array}{c}\text { Congo } \\
\text { Red }\end{array}$ & $\begin{array}{c}\text { Acid } \\
\text { Red }\end{array}$ & $\begin{array}{c}\text { Methylene } \\
\text { Blue }\end{array}$ & $\begin{array}{c}\text { Brilliant } \\
\text { Blue }\end{array}$ & $\begin{array}{c}\text { Metallic } \\
\text { Blue }\end{array}$ & Black \\
\hline \% of Degradation & 30 & 75 & 45 & 53 & 49 & 75 & \\
\hline Journal of Pure and Applied Microbiology & & 418 & & & www.microbiologyjournal.org
\end{tabular}




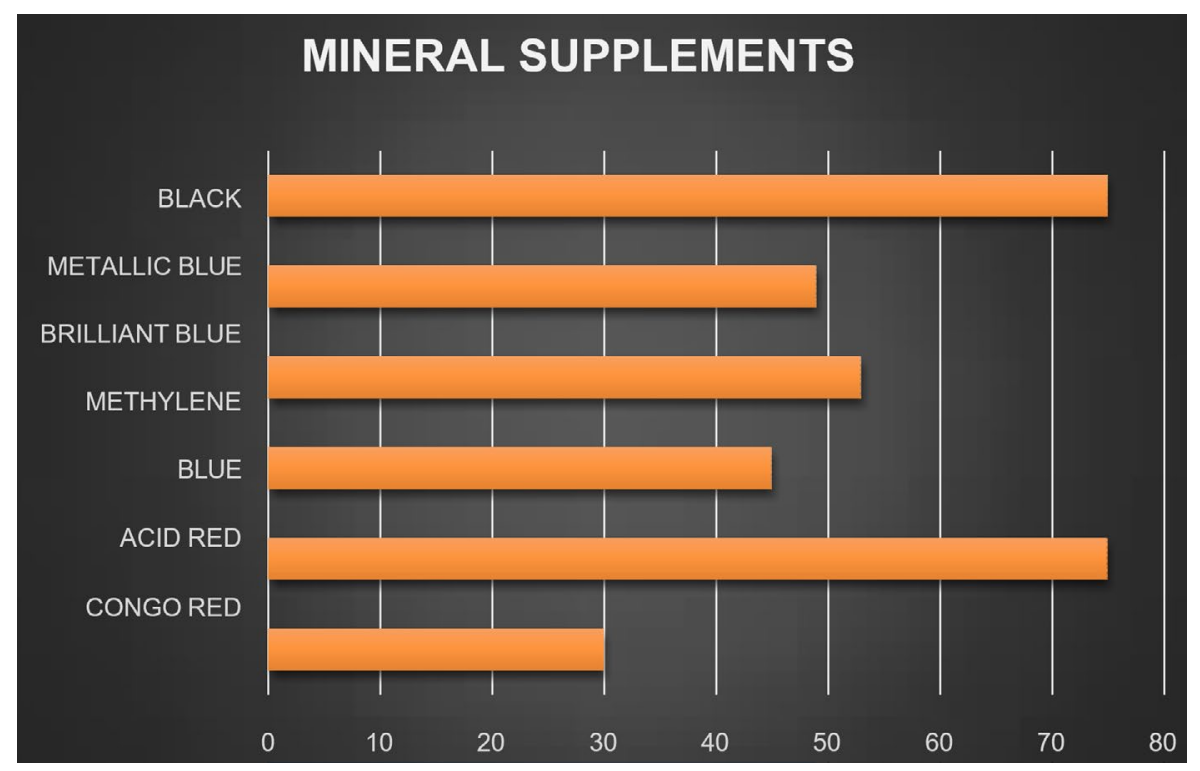

Fig. 11. Graphical Representation for Decolorization of the Dyes Statistical Representation of Degradation of the Dyes

level of degradation, the incubation time must be increased. Longer the incubation time, higher the level of degradation.

Moreover In this present study, the decolorization of the textile dyes were also done by the biological method of using enzymes. The enzyme used was laccase isolated from the fungal species Trichoderma viride. Laccase is a vital enzyme also used for the decolorization of the dyes, here culture filtrate is obtained which contains high amount of laccase. Different factors like type and amount of nutrient, $\mathrm{pH}$ factor and ability using Trichoderma viride was investigated.

The laccase enzyme assay was obtained under two conditions i.e. (with buffer and without buffer).The enzyme activity was taken at $450 \mathrm{~nm}$. The activity obtained with buffer was about 1.113 (U $\mu \mathrm{mol}-1$ ) and without buffer was 1.049 (U $\mu \mathrm{mol}-$ 1). On the basis of this present study, it was found that high amount of the laccase enzyme can be produced from the fungal species Trichoderma viride along with the substrate (Rice straw) which is cheap and used in a small amount along with the addition of certain mineral supplements in water. The enzyme which was produced was found to degrade certain reactive dyes like Congo red, Acid Red, Methylene Blue, Brilliant
Blue, Metallic Blue and Black. The percentage of degradation of the dyes were calculated by taking the absorbance of the treated dyes on hourly basis and by using the formula

(Initial Absorbance - Final Absorbance)

/ Final Absorbance) x 100.

The percentage of Decolorization is shown in the Table. 10.

From this present study, it is concluded that the laccase enzyme can be produced from the fungal species Trichoderma viride. Also, this enzyme can be used to degrade certain dyes like Congo red, Acid Red, Brilliant Blue, Metallic Blue, Methylene Blue and Black up to a certain level. So the decolorization of the dyes can be done by using the laccase enzyme and hereby treating the wastewater up to a certain level.

\section{CONCLUSION}

Thus above all we can conclude from results that the laccase enzyme from $T$. viride portrays immense potential in degrading the LDPE and textile industrial effluent dyes like Congo red, Acid Red, Brilliant Blue, Metallic Blue, Methylene Blue and Black effectively. The panoramic view from this research proves that bioremediation using laccase enzyme from $T$. viride is the 
ecofriendly and economical way of solution for pollution issue due to LDPE and textile effluent dyes.

\section{ACKNOWLEDGMENTS}

We sincerely thank the Department of Biotechnology, Karunya Institute of Technology and Sciences, Coimbatore, India for helping us to carry out this research work. We thank all the faculties who supported for carrying out this work in lab.

\section{CONFLICT OF INTEREST}

The authors declare that there is no conflict of interest

\section{AUTHORS' CONTRIBUTION}

All authors listed have made a substantial, direct and intellectual contribution to the work, and approved it for publication.

\section{FUNDING}

None.

\section{DATA AVAILABILITY}

All datasets generated or analyzed during this study are included in the manuscript.

\section{ETHICS STATEMENT}

This article does not contain any studies with human participants or animals performed by any of the authors.

\section{REFERENCES}

1. El- Batal AL, Elkenaway NM, Yassin AS, Amin MA. Laccase Production by Pleurotus ostreatus and its application in synthesis of gold nanoparticles. Biotechnology Reports. 2015;5:31-39 doi: 10.1016/j. btre.2014.11.001

2. Grover A, Gupta A, Chandra S, Kumari A, Khurana SMP. Polyethylene and Environment. International Journal of Environmental Sciences. 2015;5(6):1091-1105.

3. Amutha $\mathrm{C}$, Abhijit M. Screening and Isolation of Laccase Producers, Determination of Optimal condition for Growth, Laccase Production and Choose the Best Strain. J Bioremediat Biodegrad. 2015;6:4. doi: 10.4172/2155-6199.1000298

4. Thakkar AT, Pandya DC, Bhatt SA. Optimization of Laccase Enzyme Production by Amesia atrobrunnea
A2: A First Report. Biosci Biotechnol Res Asia. 2020;17(1):65-72. doi: 10.13005/bbra/2810

5. Goralczyk-Binkowska A, Jasinska A, Dlugonski A, Plocinski $P$, Dlugonski J. Laccase activity of the ascomycete fungus Nectriella pironii and innovative strategies for its production on leaf litter of an urban park. Plos ONE.2020;15(4):e0231453.

6. Thurston CF. The structure and function of fungal laccases. Microbiology. 1994;140:19-26. doi: 10.1099/13500872-140-1-19

7. Cuoto \& Herrera. Industrial and biotechnological applications of laccases: A review. Biotechnol Adv. 2006;24(5):500-513. doi: 10.1016/j. biotechadv.2006.04.003

8. Abadulla E, Tzanov T, Costa S, Robra K-H, Cavaco-Paulo A, Gubitz GM. Decolorization and Detoxification of Textile Dyes with a Laccase from Trametes hirsute. Appl Environ Microbiol. 2000;66 (8):3357-3362.

9. Gochev VK, Krastanov Al. Isolation of laccase producing Trichoderma spp. Bulgarian Journal of Agricultural Science. 2007;13:171-176.

10. Raju GV, Reddy MM. Isolation and Identification of Contaminants in Mass-Cultivation of Bio-Control Agent: Trichoderma viride. International Journal of Research in Pharmaceutical and Biomedical Sciences. 2013;4(3):878-885.

11. Mayolo-Deloisa K, Gonzalez-Gonzalez M. RitoPalomares M. Laccases in Food Industry: Bioprocessing, Potential Industrial and Biotechnological Applications. Front Bioeng Biotechnol. 2020;8:222.doi: 10.3389/ fbioe.2020.00222

12. Kalra K, Chauhan R, Shavez M, Sachdeva S. Isolation of Laccase Producing Trichoderma Spp. and Effect of $\mathrm{pH}$ And Temperature on its Activity. Int J Chem Tech Res.2013;5(5):2229-2235.

13. Santo M, Weitsman R, Sivan A. The role of the copperbinding enzyme- laccase in the biodegradation of polyethylene by the actinomycete Rhodococcus ruber. International Biodeterioration and Biodegradation. 2013;84:204-210. doi: 10.1016/j.ibiod.2012.03.001

14. Imran M, Asad MJ, Hadri SH, Mehmood S. Production and Industrial Applications of Laccase Enzyme. Journal of Cell and Molecular Biology. 2012;10(1):11.

15. Ojha N, Pradhan N, Singh S, et al. Evaluation of HDPE and LDPE degradation by fungus, implemented by statistical optimization. Scientific Reports. 2017;7:39515. doi: 10.1038/srep39515

16. Assila O, Tanji K, Zouheir M, et al. Adsorption Studies on the Removal of Textile Effluent over Two Natural Eco-Friendly Adsorbents. Journal of Chemistry. 2020;2020:6457825. doi: 10.1155/2020/6457825

17. Kant R. Textile Dyeing Industry an Environmental Hazard. Natural Science. 2012;4(1):22-26. doi: 10.4236/ns.2012.41004 